\title{
Collaborative support for on-line banking solutions in the financial services industry
}

\author{
H. Krassnigg \& U. Paier \\ Evolaris Research Lab, Graz, Austria
}

\begin{abstract}
Building and enhancing consumer trust in on-line banking on the World Wide Web is a critical factor in the success of e-Commerce systems. Though the number of on-line banking customers is increasing constantly in firms, there is a definite opportunity in convincing consumers to become customers. This study contributes insight into the development and growth of co-browsing and collaboration, as functionality in enabling improved on-line banking customer service and trust on the Web. Defined in the study are the benefits of building components of e-Services, consisting of collaborative guidance tools, preemptive support tools, and responsive service tools. The focus of the study is on benchmarking a sample of financial service firms and of tools of trust and on introducing an interactive advisor as a collaborative on-line banking service and tool of trust. The paper evaluates as an in-depth case study the functionality of interactive advisor tools and the benefits of the tools in enabling trust for on-line banking customers on the Web. This study will benefit business management practitioners and researchers in the financial services industry that are exploring continued opportunity and risk in on-line banking solutions of trust on the Web. Keywords: customer retention and recovery, e-Services, interactive help desk, tools, trust, trust building and trust building components.
\end{abstract}

\section{Introduction}

\subsection{Lack of customer trust}

An important success factor for on-line banking is to be able to create and increase the customer's trust in e-Commerce service [1]. Although the number 
of on-line banking users is constantly increasing [2], there is still far more potential to reach and convince new customers.

With the cumulative acceptance and spread of internet based technologies, potential business in the field of electronic commerce grows. Despite the boom in on-line banking [3], there are uncertainties which are strongly anchored in the consumers [4]. The uncertainties, as perceived by the consumer, stem especially from the lack of trust in the use but also through the virtuality and the spatial separation and the aggravated assessment of the trust of the supplier [5]. Furthermore, there are insecurities due to the security of Internet communication. Due to the numerous amounts of suppliers furnishing the customer a service, the customer is often uncertain of the service [6].

The cultivation of trust, however, can be positively influenced by the supplier with appropriate measures. This can also occur when many exogenous factors take effect on the cultivation of trust, which lie outside of the realm of influence of the supplier. Trust management will then find access to, for example, the areas of customer retention management, complaint management, service management, etc. The goal of trust management is to overcome (with on-line banking) risks and to build up a long term and continual trust relationship between the supplier and the customer [7].

\subsection{Customer retention and recovery through raising trust}

\subsubsection{Process oriented approach}

In e-Commerce, the sales process, according to Riemer and Totz [8], is classified in four phases: information, initiation, development and after sales. The contention of the paper is that this must be complemented with a fifth phase, namely the area of exception handling, which should be observed in each of the four phases in Figure 1.

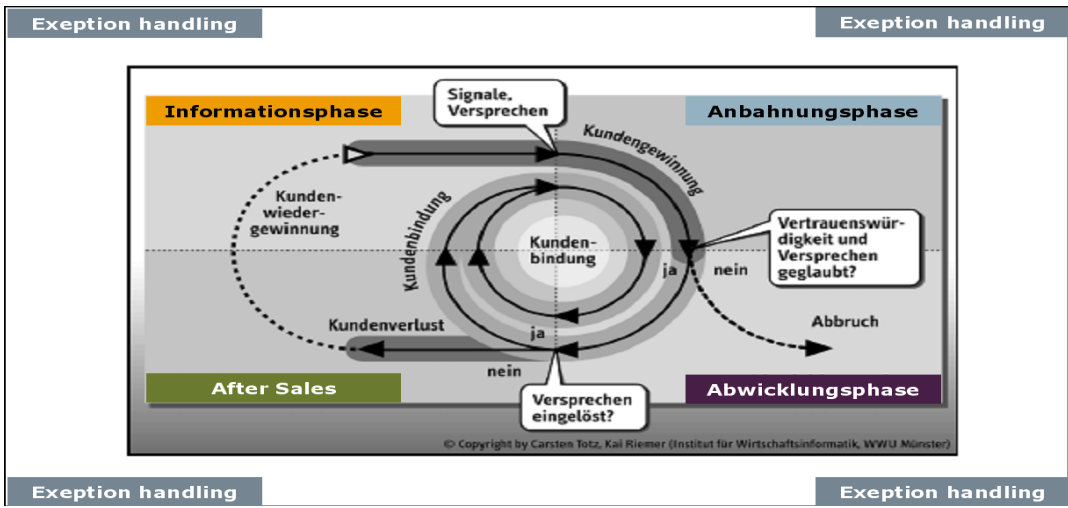

Figure 1: Customer retention cycle from Riemer and Totz expanded through exception handling. 
With customer retention, all phases will be run through. For customer recovery, it is necessary to run through all four phases, and retention requires more run throughs.

The pre-conditions for a successful business transaction are the creation of trust, which should be signalled by the supplier to the customer during the information phase. If the expectations of the customers are fulfilled or the supplier exceeds them, then the customer will step into a new business relation with the supplier, which can then lead to the retention of the customer [9]. If the customer trusts the supplier, then there is a possibility for customer retention. This will then be consolidated through the rising trust and maintained measures and will be kept intact [10]. Also, in the field of financial service, all four phases of the e-Commerce problems could arise, which could lead the customer not to close a transaction and to leave the cycle. If, however, in the scope of exception handling, he/she is optimally handled, then he/she can be brought back into the cycle. A customer dissatisfied and the consequential loss of trust can then be turned around, and this then considerably strengthens the customer retention.

\subsubsection{Problem oriented approach}

According to the problem oriented approach, the contentedness and the trust of the customer can be increased through the support of the simple tools and appplication, in case a problem with utilization occurs with the tools [11]. These can increase the trust, which is why some of them can be viewed upon as trust building components $[12,13]$, which can be divided into three different types of on-line customer services below and in Figure 2 [14].

- Responsive service tools: These enable the customer service inquiry to begin and offer an automatic support without being steered by a person. In this manner, customers have the possibility to initiate a service when they have a problem, which is usually without personal support of an employee in helping to solve the problem. Possible examples for these types of applications are: search, virtual agents, frequently asked questions, automated e-mail, self-service transactions, interactive knowledge base, checking images, online statements, and Avatare.

- Collaborative guidance tools: These accomplish a personal connection between customer and agent, in which the customer is able to request human help during a sales or service interaction. In order to enable the customer to have personal support during a transaction, a connection with an employee will be generated by the tools. Examples of applications are chat, collaboration, co-browsing, joint form filling, and instant messaging.

- Pre-emptive support tools: Through pro-active service, specific circumstances of the customer can be solved already before a problem occurs and, therefore, exceed customer expectation. Examples are news, account based alerts, status alerts, and actionable two-way alerts. 


\section{Methodology}

The evolaris research lab of the authors of the study analyzed the largest 20 banks in their qualitative benchmarking study, and the findings detected 17 confidence-raising tools and applications. The benchmarking study reached the goal of identifying applications and technologies which would contribute to the confidence rising and, therefore, assist in customer retention in on-line banking. This study incorporated financial service businesses [15] and businesses from other trust sensitive branches [16], in order to identify e-Services and tools, which could support a rising in trust for digital transactions.

Differences in the applications were found mainly in the area of customer support in case of a problem. According to the available results, there is a clear trend in favor of responsive services. The most common examples in this connection are frequently asked questions, different demonstration applications, and calculators. These services are geared so that the customer can solve the problem without the interaction of a bank employee, such as frequently asked questions, downloads, and search engines.

Only a few banks are able to offer their customers applications, which furnish an interaction between the customer and the bank employee (interactive consultancy and chat applications). In the area of collaborative guidance, applications yield to new possibilities in customer service through co-browsing (cross screen comparison) and a direct approach with the customer via an available telephone connection (call back).

The least available are applications from the area of pre-emptive support, in which the customer is pre-supplied with information before the problem occurs or is even prepared with alternatives in order to avoid problems. In this group, are mainly those with a definable automatic alert via different channels, such as e-mail. Information is mainly transmitted for account coverage, and subscription respites from shares [17].

Financial service firms must check in which phase they need to catch up in. Once this is determined by firms, a systemic application of the trust building applications and technologies in this phase can follow [18].

An increase in the customer satisfaction and a decrease in the rate of abort during a transaction can be obtained if during all occuring problems support is offered to the consumer on the basis of simple applications [19]. This support through value added services raises the effectiveness and usage, lowers the costs and leads therefore to a customer recovery and retention. Successful firms use a combination of the three types on on-line services.

In order to enable customers to have personal support in the course of a transaction in on-line banking, the bank has to set up a connection between the customer and the employee, who can assist during the problem solving [20]. Examples of applications in this area are collaborative guidance, which is technically based solutions, such as chat, collaboration, co-browsing, joint form filling, and distant messaging. 


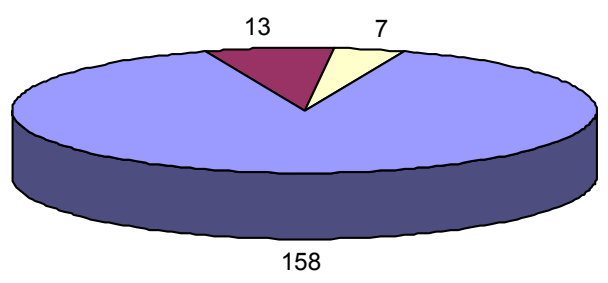

Figure 2: Results of division of e-Services from evolaris benchmarking study.

This paper is focused on the collaboration and co-browsing service, known as interactive advisor. Following will take a look at the function principle, the utilization for the customer and the bank, as well as potentials from this application. Also, technical aspects of this collaborative service will be covered in the paper.

\section{Analysis}

\subsection{Functional description of interactive advisor}

The interactive advisor in Figure 3 allows customer support when problems occur in connection with an on-line banking transaction.

During the navigation (filling out a form or using the Web based calculation module), the customer clicks on the integrated button, to interactive advisor on the Web form. In the next step, a pop-up opens, in which the customer has the possibility to type in his telephone number or e-mail address. Depending on which configuration, the customer now sees either a new browser window for the text-chat, or the screen sharing would be initiated by the tools. In case of screen sharing, the customer has to activate a signed Java applet through a download. Screen sharing can also be initiated during a telephone call, in which the employee gives the customer an ID, which he would then use in order to have a connection.

In this manner, one can fill out an application form together or one can explain the problem at hand to the customer. This is established by screen comparison. The consultation through the Web, also known as e-Consulting, relates to the technical questions as well as content problems with the content 
matter, which would be in connection with the products and services offered by the bank [21].

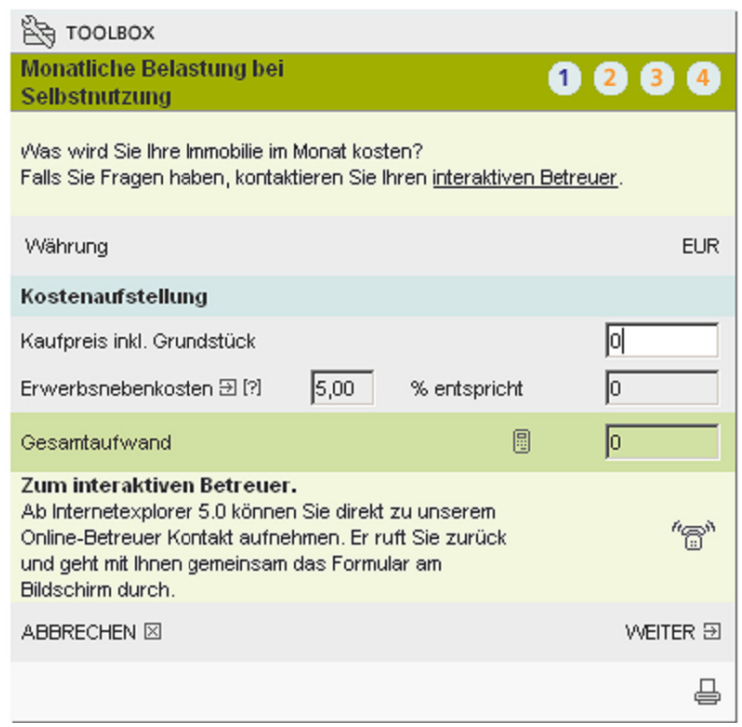

\begin{tabular}{|c|c|}
\hline \multicolumn{2}{|c|}{ Interaktiver Betreuer } \\
\hline \multicolumn{2}{|l|}{ '莤' } \\
\hline \multicolumn{2}{|c|}{$\begin{array}{l}\text { Bitte beachten Sie, dass wir Sie nur } \\
\text { innerhalb Deutschlands zurückrufen } \\
\text { können. Um den interaktiven Betreuer } \\
\text { zu nutzen, müssen Sie gleichzeitig der } \\
\text { Internet-Zugang und eine Telefon- } \\
\text { verbindung aufbauen können, z.B. mit } \\
\text { einem Doppelanschluss oder einem } \\
\text { ISDN-Anschluß }\end{array}$} \\
\hline \multicolumn{2}{|c|}{$\begin{array}{l}\text { Betreuungszeiten: } \\
\text { *ontag bis Freitag von } 8 \text { bis } 22 \mathrm{Uhr} \\
\text { * Samstag und Sonntag von } 10 \text { bis } \\
18 \mathrm{Uhr}\end{array}$} \\
\hline \multicolumn{2}{|l|}{ Nachname } \\
\hline \multicolumn{2}{|l|}{ Vorname } \\
\hline \multicolumn{2}{|l|}{ (c) Telefon } \\
\hline \multicolumn{2}{|l|}{$\mathrm{O}$ Betreuer ID } \\
\hline 冈Abbreche & Verbinden 9 \\
\hline
\end{tabular}

Figure 3: Interactive Advisor of Hypovereinsbank (calculation form).

\subsection{Economical aspects}

\subsubsection{Supplier}

There are various software suppliers in this area [22]. The following descriptions arise from the product, Aspect Web Interaction, from the firm, Aspect Communications Corporation [23]. This is used for example by the Hypovereinsbank [24] .

\subsubsection{Utilization}

The customer can use, free of charge, this tool in on-line help and resolve problems. Through the help of the employee, who guides the customer through different processes, the financial service firms can decrease the rate of abort during on-line orders and calculations and can increase customer satisfaction through the service advantage, and this is where the customer retention is initiated by the tools. Customer trust can be increased through the advice performance, which is a crucial success factor in on-line banking. Technologically experienced customers are approachable through the innovative e-Service, which in turns enhances customer recovery [25].

The sessions, including the text chats, can be recorded, which gives hints as to how to improve the service and the information content [26]. 


\subsubsection{Implementation}

In order to have such an extensive system, the bank has to first of all have a customer service center or a call center as the case may be in the firm. The implementation of this service would offer the financial service firm the following features [27]:

- Call-Back-Service on any of the clients' desired Web site;

- Automatic call back to the customer from the best suited agent in the customer care center;

- Synchronized browsing in a joint session (escorted browsing);

- Simultaneous telephone calling and browsing during simultaneous utilization from two canals through ISDN or cellular telephone);

- Interactive marking and flagging of the content through the agent on the Web site;

- File-Transfer during the telephone call; and

- Web-Conferencing (meet me).

Prerequisites for a successful implementation furnish the following:

- Provision of necessary hard and software (e.g. Fujitsu-Siemens Primergy $\mathrm{H} 250$ and W2K Advanced Server);

- Provision of necessary technical infrastructure in the customer care center (e.g. Siemens Hirocm 300E telephone system and ProCenter Software for the agents' work stations); and

- Documentation of the dialogue and communication process between the customer and the consultant on the Web site.

\subsubsection{Risks}

The visualized system requires encroachments in the technology and influences the function of the customer consultant in the branches. There is the risk that the qualified consultant does not accept the tool, because he fears that he will be replaced by call center employees.

Because of this, employee training is necessary. There is also a risk of customer acceptance. For one thing, the customer is not familiar with the procedures, and for another, there are technological utilization barriers with the customers, although this deals with on-line banking clients [28]. In any case, it will be difficult to charge for something in the long run which is being offered for free in the short run, or to charge for the service in the beginning. Also, the accessibility of potentially available customer relationship management (CRM) solutions, or customer data bank associated with a certain amount of expenditure, is a risk.

\section{Technology}

\subsubsection{System structure and interfaces}

The Web interaction server includes the Web interaction application server in Figure 4, which runs under the IBM WebSphere and serves primarily the provision of the Web based client for the customer interface. It is not necessary to have a connection to the corporate Web server, in order to enable an 
integration of the application on the customer's Web site without a break. The automatic forward of questions from the logged-in customer is directly handled on the desktop of a consultant from Aspect Enterprise Contact Server, which delivers all relevant information for the follow-up chat with the consultant in the bank or in the call center of the firm.

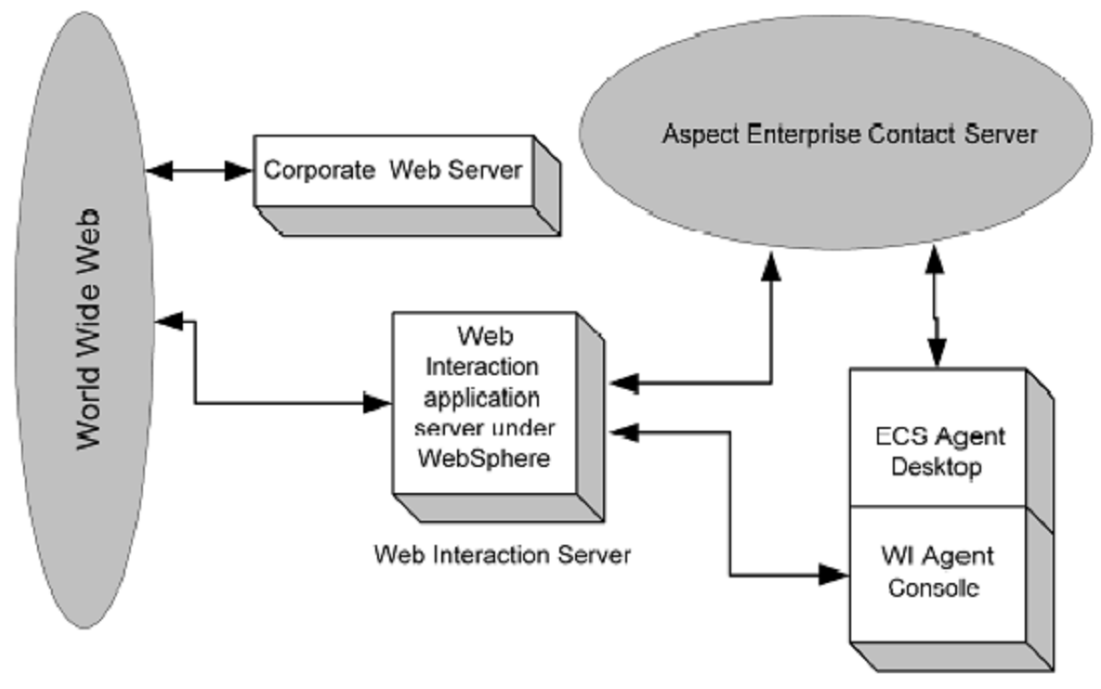

Figure 4: Comprehensive depiction of application server [30].

\subsubsection{Availability}

The system can apply the load-balancing possibilities of the underlying server. In this manner, the extensive calculations and large amounts of questions can be channelled through numerous systems, all functioning concurrently.

The manner of distributing the processes to the processors has a huge influence on the whole performance of the system, because, for example, the Cache-content is local for every processor.

In responding to the http requests, systems are already switched on (front-end server), which then distribute the individual questions to the back-end server, according to assigned criterion.

The load balancing is a mechanism to safeguard against failure. Through the building of a cluster and the distribution of requests to single systems, one reaches a high level of safeguarding against failure, as long as the failure of a system is recognized by the tools, and the requests are automatically passed on to another system [29]. This function is only limited through the possibilities of the customer adviser employee and only reaches in a cost effective variation the business hours. 


\subsubsection{Security}

The software allows itself to be conducted not only in internal networks (possible with IIS 4.0, IIS 5.0 and iPlanet 4.x Enterprise Edition on Solaris), but also in a demilitarized zone (DMZ). With this variation the server is in the DMZ. In this case, the MS IIS 5.0 webserver should be used by the system.

Following ports are employed by the system:

- Port for Web Interaction Application Server on Websphere: 80 (http) and 443 (https) respectively. Two way TCP/IP and http or as the case may be https with SSL coded variation;

- Aspect DataMart (responsible for reporting): Port 5001 two way TCP/IP; and

- Enterprise Contact Server ECS: Port 9001 2-Weg TCP/IP (blocks at external firewall).

\subsubsection{Anti-virus Software}

This software is to be used in combination with the available Web server, wherefore the same anti-virus protection measures can be met by the system. The customer has no possibility to distribute a feasible code from his/her computer to the workstation from the employee. Therefore, the risk to get infected is credible.

The customer has to activate an applet (for Internet Explorer), or as the case may be a signed script (Netscape), through a download. These are, however, declared safe because these are signed and therefore are rated in Internet Explorer and Netscape as harmless.

In order to further increase security, one could install "agent desktop" software behind the firewall. These could be obtained from the terminal services.

\subsubsection{Back-up}

Just like the topic concerning anti-virus protection, the same system that was used for the Web server can be used for the back-up. In due time, a three way distribution for the back-up will be necessary because of the backing up of individual systems. Concerning the back-ups of the individual systems, soon it will be necessary to use a tri-section back-up because of the difficulties experienced in retrieval.

In this manner, Aspect enterprise contact server can be securely separated from both of them in the DMZ situated systems (Web interaction server and corporate Web server). The advantage of the backed up data is that when a failure of the entire system occurs, then the corporate Web server can be recovered independently of the other systems.

\section{Other technology}

Due to the high costs a call center creates for a financial service firm, the firm has the possibility to use a virtual customer consultant agent, instead of a personal contact like with the interactive advisor in Figure 5. In order to find appropriate examples, paper refers readers to Sparda-bank Nürnberg eG [30] and the Bausparkasse Schwäbisch Hall AG [31] in Germany. Both firms place 
emphasis on technology from Kiwilogic.com AG [32], which has already implemented approximately 100 virtual agents internationally [33].
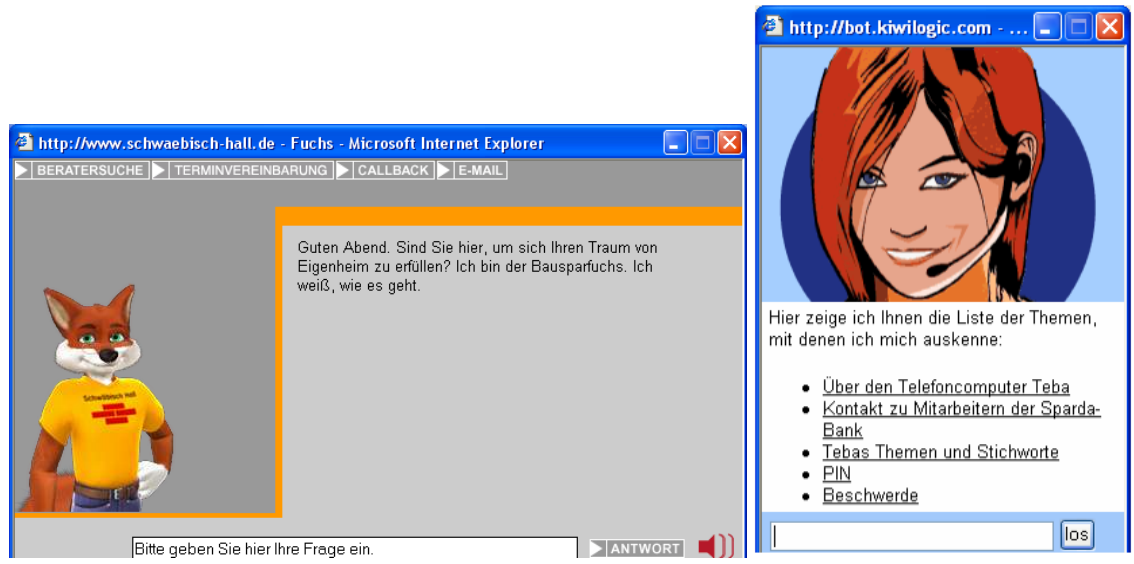

Figure 5: $\quad$ Interactive advisor (entry form).

The above illustrated adviser [34] receives the re-entries from the customer through a simple HTML-form located in the Web browser. After dispatching the re-entries, the entries from the Web engine are further prepared through a common gateway interface (CGI). The answer is then searched within the knowledge base. The transferred keywords of the customer will then be compared with the questions already deposited in the data bank. Resulting consistencies will then be sent back to the customer. The answer text, as well as graphics depicting the mood, will be sent to the customer. Finally, those Web sites containing information that the customer has requested will be automatically recalled by the system.

\section{References}

[1] Kundisch, D., Building trust - the most important crm strategy?. Proceedings of the $3^{\text {rd }}$ World Congress on the Management of Electronic Commerce: Hamilton, pp. 1-14, 2002.

[2] Jung, C., Internet und on-line banking: warum offliner offliner sind. Die Bank, 4, pp. 282-283, 2004.

[3] Forrester Research, Inc., Efficient multi-channel banking. February, 2002.

[4] Forrester Research, Inc., Experience - the key to on-line security issues. February, 2002.

[5] Petrovic, O., Fallenböck, M., \& Kittl, C., Der paradigmenwechsel in der vernetzten wirtschaft: von der sicherheit zum vertrauen, in Petrovic, O., Ksela, M., Fallenböck, M., \& Kittl, C., (eds.). Trust in the Network Economy, Springer-Verlag: Vienna and New York, pp. 3-28, 2003. 
[6] Demunter, Internetnutzung in Europa: Sicherheit und Vertrauen, http://epp.eurostat.cec.eu.int/cache/ITY OFFPUB/KS-NP-05-

025/DE/KS-NP-05-025-DE.PDF, On-line banking security: give customers more control and reassurance. January, 2006.

[7] Riemer, K. \& Totz, C., Nachhaltige Kundenbindung durch Vertrauensmanagement, in Klietmann, M., (ed). Kunden im E-Commerce. Verbraucherprofile - Vertriebstechniken - Vertrauensmanagement, Symposium Verlag, pp.175-199, 2000, and Riemer, K. \& Totz, C., Vertrauensmanagement - Loyalität als Schlüsselgröße, in Internetshopping

Report 2001: Käufer, Produkte, Zukunftsaussichten, p. 339, 2001.

[8] Riemer, K \&, Totz, C., in Klietmann, M., (ed). Kunden im E-Commerce, p.183, 2001.

[9] Riemer, K \&, Totz, C., in Klietmann, M., (ed.). Kunden im E-Commerce, pp.183-185, 2001.

[10] Petrovic O. \& Kittl, C., Trust in digital transactions and its role as a source of competitive advantage in the network economy, Proceedings of the IADIS International Conference, Carvoeiro, Portugal, 2003.

[11] For a model of trust, refer to Petrovic, O., Fallenböck, M., Kittl, C., Wolkinger, \& T., Vertrauen in digitale Transaktionen. Wirtschaftsinformatik, 45(1), pp. 53-66, 2003.

[12] Ba, S. \& Pavlou P., Evidence of the effect of trust building: technology in electronic markets: price premiums and buyer behaviour. MIS Quarterly, 26(3), pp. 243-268, 2003.

[13] For trust building components and strategies, refer to Urban, G., Sultan, F. \&, Qualls, W., Placingt trust at the center of your internet strategy. Sloan Management Review, Fall, pp. 39-48, 2000.

[14] Forrester Research, Inc., On-line service: the next generation, September, 2002.

[15] Citigroup, Bank of America, Egg, UBS, Advance Bank, Credit Suisse, Abbey National, Deutsche Bank, ING Postbank, National Australia Bank, Commerzbank, ICBC, HypoVereinsbank \& Lloyds TSB Bank, 2002.

[16] Trust sensitive branches, such as insurance and notary health care, 2002.

[17] Evolaris Benchmarking StudieVertrauenssteigerung durch neue e-Services als Trust building components, 2002.

[18] Gomilschak, M. \& Kittl, C., The role of trust in internet banking. Proceedings of the MIPRO 2004 Conference, May, Opatija, Kroatien, pp. 24-28, 2004.

[19] For rate of cancellation and reasons for not using the on-line banking, refer to Forrester Research, Inc., Why on-line banking users give up, May, 2002.

[20] Dührkoop, Strategische Erfolgsfaktoren für das Online- Angebot von Privatbanken, October, 2001. 
[21] The description of the interactive advisor was conducted during proceedings with the Hypovereinbank, 2001.

[22] Chordiant Software, Inc., http://www.chordiant.com/home.html.

[23] Aspect Communications Corporation, http://www.aspect.com/index.cfm.

[24] Bayerische Hypo- und Vereinsbank AG, http://www.hypovereinsbank.de/pub/home/home.jsp.

[25] Naef, A., Maintaining customer relationships across all channel Proceedings of Financial Services Europe, 13 October, London, UK, 2005.

[26] Holzhauser, A., E-CRM - E-Service, http://www.factline.com/154848.0/.

[27] Aspect Communications Corporation.

[28] Jung, C., Internet und On-line banking: warum offliner offliner sind. Die Bank, 4, pp. 282-283, 2004.

[29] For load balancing, refer to Article Lastverteilun, in: wikipedia, die freie Enzyklopädie, Bearbeitungsstand, 16 December, 2005, http://de.wikipedia.org/w/index.php?title=Lastverteilung\&oldid=1170701 4.

[30] http://www.sparda-telefonbank.de/wer.html.

[31] http://www.schwaebisch-hall.de/.

[32] http://www.kiwilogic.de/.

[33] http://www.kiwilogic.de/.

[34] Kiwilogic Lingubot Software, Kiwilogic.com AG. 